Transportation Research Forum

On the Stock Market's Reaction to Major Railroad Accidents

Author(s): Thomas J. Walker, Kuntara Pukthuanthong, and Sergey S. Barabanov

Source: Journal of the Transportation Research Forum, Vol. 45, No. 1 (Spring 2006), pp. 23-39

Published by: Transportation Research Forum

Stable URL: http://www.trforum.org/journal

The Transportation Research Forum, founded in 1958, is an independent, nonprofit organization of transportation professionals who conduct, use, and benefit from research. Its purpose is to provide an impartial meeting ground for carriers, shippers, government officials, consultants, university researchers, suppliers, and others seeking exchange of information and ideas related to both passenger and freight transportation. More information on the Transportation Research Forum can be found on the Web at www.trforum.org. 


\section{On the Stock Market's Reaction to Major Railroad Accidents}

This study examines the impact of train accidents on the stock price performance of the involved railroad companies. We employ a sample of 26 accidents involving trains operated by publicly traded U.S. and Canadian railroad companies between January 1993 and December 2003. Event study methodology is used to measure the abnormal performance of the involved railroad firms to these accidents. In addition, a series of univariate tests and cross-sectional regression analysis is employed to determine the factors that drive the abnormal returns for the firms in the sample. The magnitude of the initial price decline appears to be driven by various characteristics of both the firm and the accident itself. Specifically, there is strong evidence that suggests that one of the main determinants of the abnormal returns is expected legal liability claims against the railroads. Abnormal performance is negatively related to firm size and the number of injuries and fatalities resulting from the accident. In addition, accidents that result in hazardous material spills cause significantly larger stock price drops in the days following the event. Finally, investors appear to differentiate between accident causes. Accidents caused by reckless or illegal behavior on behalf of one or more of the railroad company's employees result in particularly large price declines. Accidents caused by mechanical failures or signal malfunctions, on the other hand, only cause small stock price drops.

\section{by Thomas J. Walker, Kuntara Pukthuanthong, and Sergey S. Barabanov}

\section{INTRODUCTION}

Although the North American railroad system is widely viewed to be one of the safest and most efficient in the world, the ever-increasing speed and size of today's trains makes every accident a potentially disastrous one. In contrast to aviation accidents, which frequently involve a high number of casualties, the majority of railroad accidents in recent years have resulted in comparatively small losses of human life. Yet, because the railway system provides the preferred means for transporting hazardous materials over large distances, railroad accidents involve a substantially higher risk of resulting in ecologically disastrous spills of toxic chemicals, fuel, and radioactive materials (to name a few), which is rarely the case in aviation accidents. ${ }^{1}$

This paper investigates the economic consequences of a railroad accident from an investor's point of view and examines the stock price performance of publicly traded U.S. and Canadian railroad companies following train accidents. As a result of a train accident, the involved railroad companies are frequently the target of a plethora of legal liability claims filed by the surviving relatives of the accident victims or the surviving, but injured, accident victims themselves. In addition, in cases where a railroad accident results in a hazardous material spill, railroad companies are usually liable for third-party damages and the required cleanup costs.

Although railroad companies are typically insured against liability claims, train accidents cause significant price declines for the involved firms. We argue that legal costs, diversion of management time, rising insurance premiums, repair and/or replacement costs for the damaged train and its cargo, and loss of consumer confidence accompanied with fewer passenger bookings or cargo hauls represent real costs for the involved firms.

The analysis follows Chance and Ferris (1987), who study the stock price reaction of airlines and airplane manufacturers following an airplane crash using a sample of 46 aviation 
disasters between 1962 and 1985. Chance and Ferris (1987) observe a significant price reaction for airlines but not for airplane manufacturers on the day of the crash. Similarly, Davidson et al. (1987) employ a sample of 57 crashes over the period 1965 - 1984. They observe a significant price decline for airlines on the day of the crash. In their sample, the negative returns are reversed in the days following the crash. Finally, Thiengtham and Walker (2005) employ a sample of 174 aviation disasters involving airplanes operated by publicly traded U.S. carriers between January 1950 and December 2004 and observe that investors are highly sensitive to potential legal liability claims when determining the new stock price equilibrium for the involved airline company and airplane manufacturer.

While the stock market effects of aviation disasters have been sufficiently studied, there is to our knowledge no study that performs a similar analysis for railroad accidents. Studies that examine the financial consequences of railroad accidents typically focus on direct costs for the involved railroad company or the affected communities. ${ }^{2}$ Yet, it is important to understand how investors react to such accidents. The paper attempts to fill this gap by analyzing both the short-term and long-term impact of train accidents on the stock prices of the involved railroad firms using a sample of 26 major accidents that occurred between January 1993 and December 2003. ${ }^{3}$

In addition, the paper adds to the existing literature by not only measuring the magnitude of the stock price reaction, but by examining why investors tend to react differently to different types of accidents. To accomplish this, a series of univariate tests and cross-sectional regression analysis is employed to measure the effect of various characteristics of the accident on the abnormal performance of the involved firms. Particular attention is paid to the causes and consequences of each accident, and whether investors incorporate expected legal liability claims into their trading decisions. In addition, the paper examines whether certain types of railroad firms are more affected than others.

Finally, the study examines whether investors react rationally to accident announcements. It is expected that railroad company stocks drop after an accident. What is interesting from an academic point of view is whether investors are able to quickly predict the price of a stock after an accident, as is suggested by the efficient market hypothesis of Fama et al. (1969). The results indicate otherwise (i.e., we find a clear violation of the efficient market hypothesis) as initial stock price declines for railroad firms during the first day of trading are consistently followed by additional declines during a period of few days, and an almost complete reversal within approximately two weeks. ${ }^{4}$ The results are robust to the removal of outliers and variations in sample construction and methodology.

The results of this study are consistent with Thiengtham and Walker (2005), who observe a strong relationship between legal liability concerns and stock price reactions for large aviation disasters. In addition, the findings of a continued price decline that persists for several days after the event, and the subsequent reversal, is similar in nature to the stock price reversal observed by Davidson et al. (1987). At the same time, the results are contrary to the findings of Sprecher and Pertl (1983), who study a cross section of industries and observe that large losses had a negative effect on stock returns with no reversal in the first few days following the losses. ${ }^{5}$

The paper is organized as follows: The following section explains the methodology used to test several hypotheses concerning the stock performance of railroad companies following train accidents. The data section describes the data sources and defines the variables used in the analysis. The last two sections present the empirical results of the analysis and provide concluding remarks.

\section{METHODOLOGY}

Event study methodology was used to measure the abnormal stock price performance of railroad companies following train accidents. Event study methodology measures the abnormal return of a stock as the difference between the actual return and the expected return, around the time of an event. Event studies draw on the efficient market hypothesis of Fama et al. (1969), which states that capital markets are efficient in 
processing information by establishing a correct new stock price equilibrium as soon as new information about a firm becomes available. The logic underlying the hypothesis is the belief that investors in capital markets process publicly available information on firm activities and external events influencing a firm, and that they consider not just the impact on current performance but also on the performance of the firm in future periods. When additional information becomes available, the firm's stock price should change rapidly and should reflect investors' revised consensus of the firm's future profitability.

The strength of the method lies in the fact that it captures the overall assessment by a large number of investors of the discounted value of current and future firm performance attributable to individual events, which are reflected in the stock price and the market value of the firm. Changes in investors' beliefs regarding the future profitability of a firm are reflected in abnormal returns - risk adjusted returns less than the firm's expected return - following the accident. Abnormal returns thus provide a unique means of associating the impact of an accident announcement on the firm's expected profitability in future periods (McWilliams and Siegel 1997).

In the transportation sector, there is significant empirical support for the efficient market hypothesis, including the Carter and Simpkins (2004) and Flouris and Walker (2004) studies of airline stocks following 9-11. Event studies have also been applied in other industry sectors. Hill and Schneeweis (1983) and Bowen et al. (1983), for example, use event studies to examine the effect of the 1979 Three Mile Island accident on utility stocks. In addition, event study methodology is widely used in insurance studies that evaluate the effects of various kinds of disasters on the stock performance of insurance companies. ${ }^{6}$

To calculate the effect of an event, it is necessary to estimate what the price of the stock would have been had the event not occurred. To do this, and to control for overall market effects, the price of the stock is regressed against a stock market index. The estimated coefficients from that regression are used to calculate the predicted value of the stock over the time window in which the stock price is adjusted. This yields the regression:

$$
\text { (1) } R_{s, t}=\beta_{0}+\beta_{1} R_{m, t}+\varepsilon_{s, t}
$$

where $R_{s, t}$ is the return of stock $s$ at time $t: R_{s, t}=\left(\right.$ Price $_{\mathrm{s}, \mathrm{t}}-$ Price $\left._{\mathrm{s}, \mathrm{t}-1}\right) /$ Price $_{\mathrm{s}, \mathrm{t}-1}$. If the firm paid a dividend during the event window, it is included in the return calculations. The subscript $t$ indicates time, the subscript $s$ indicates a specific stock, and the subscript $m$ indicates the market. The $\varepsilon_{\mathrm{s}, \mathrm{t}}$ is a random error term for stock s at time $t$, and the $\beta$ 's are coefficients to be estimated. For this study, the S\&P 500 or the TSE 300 index was used to proxy for the U.S. or Canadian market, respectively.

The date of the event is denoted as $t=0$. To estimate the expected return, data from $t=[-750,-1]$ (i.e., 750 trading days, or approximately three years, of pre-event data) is used. Several other intervals were considered with no significant difference in the results. In addition, several other methods of calculating a firm's expected return were considered, again with no significant differences. ${ }^{7}$

The coefficient estimates from regression (1) were used to predict the expected return over various post-event windows. To estimate the abnormal return of a stock on day t, $A R_{s, t}$, this paper follows Brown and Warner (1985) and subtracts the expected return on the stock from its actual return on that day:

(2) $A R_{s, t}=R_{s, t}-\left(\beta_{0}+\beta_{i} R_{m, t}\right)$

The coefficients $\beta_{0}$ and $\beta_{1}$ are estimates of the true parameters obtained via ordinary least squares (OLS) regression. The abnormal returns are simply the prediction errors of the model over the event window. Notice here that $A R$ are abnormal returns; that is, they are returns over and above the return predicted by general market trends on a given day. The assumption of the methodology is that the abnormal returns are the result of the announcement and not some other random event occurring on the same day. The strength of the method is linked to the improbability of random events across different firms on different days coinciding with the announcement of a railroad accident. The standard errors are calculated by the formula 
defined by Judge et al. (1988):

(3)

$$
\operatorname{var}\left(A R_{s, \tau}\right)=\left(S_{S}^{2}\left[1+\frac{1}{T}+\frac{\left(R_{m, t}-R_{M}\right)^{2}}{\sum_{t=1}^{T}\left(R_{m, t}-R_{M}\right)^{2}}\right]\right)
$$

where $S_{S}^{2}$ is the variance of the error from the estimation model, $R_{M}$ is the mean market return over the prediction interval, and $T$ represents the number of days in the estimation interval. The $\tau$ indicates observations within the event window, while the $t$ indicates observations in the estimation interval. Notice that the standard error on any given day $\tau$ of the prediction interval is a function of how much the actual market return on that day deviates from the mean market return during the estimation interval. Thus, on days on which the market return is very different from the expected market return the standard errors of abnormal returns are greater. Notice also that the standard error depends on the length of the estimation interval, such that longer estimation intervals lead to lower standard errors.

Under the assumption that the returns on each day are independent, the standard errors are cumulative, so the proper standard error is the cumulative standard error. This is because adding independent normal variables requires adding the standard errors. Thus, we have the following equations to describe the cumulative abnormal returns (CAR) over time for a given stock for a given accident, and the variance of the cumulative abnormal returns, $\operatorname{var}(\mathrm{CAR})$ :

$$
C A R_{s, \tau}=\sum_{i=0}^{\tau} A R_{s, i}
$$

and

$$
\operatorname{var}\left(C A R_{s, \tau}\right)=\sum_{i=0}^{\tau} \operatorname{var}\left(A R_{s, i}\right)
$$

From these equations we can calculate the average CAR across all $\mathrm{N}$ firms in the sample and the variance of the CARs. The resulting equations are:

(6) $\overline{C A R_{\tau}}=\frac{1}{N} \sum_{s=1}^{N} C A R_{s, \tau}$

and
(7) $\operatorname{var}\left(\overline{C A R_{\tau}}\right)=\frac{1}{N^{2}} \sum_{s=1}^{N} \operatorname{var}\left(C A R_{s, \tau}\right)$

To test the hypothesis that the mean CAR is different from zero on any given day, one would use a Student's t test which, under the null hypothesis of zero returns, is of the form:

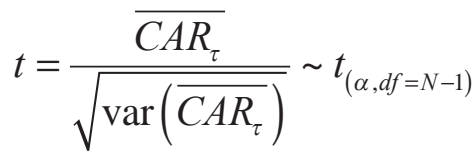

The null hypothesis to be tested is that the mean excess return during a given event windows is equal to zero. It is assumed that the return is negative, thus, a one tailed t-test is applied. In addition, because t-tests are based on strong assumptions about the underlying return distribution, a Wilcoxon signed rank test (a non-parametric test) was used to ensure the robustness of the results. In a Wilcoxon test, both the sign and the magnitude of the abnormal performance are taken into consideration when calculating the test statistic.

To shed some light on the cross-sectional determinants of the stock market's reaction to a railroad accident announcement, the study explores the relation among the cumulative abnormal returns around the event and various factors that describe the accident as well as the involved firm itself. To accomplish this, OLS regressions are used as follows:

$$
C A R_{s, \tau}=\alpha_{0}+\alpha_{1} x_{1 s}+\ldots+\alpha_{n} x_{n s}+\varepsilon_{s}
$$

where $\mathrm{x}_{1 \mathrm{~s}}, \ldots, \mathrm{x}_{\mathrm{ns}}$ are $\mathrm{n}$ factors that describe firm $\mathrm{s}$ or the railroad accident involving the firm, and $\varepsilon_{\mathrm{s}}$ is the zero-mean error term that is uncorrelated with the X's. $\alpha_{0}, \ldots, \alpha_{n}$ are the regression coefficients of themodel. Regression results are reported for cumulative abnormal returns calculated over periods of 1 to 21 trading days following an accident to examine both the immediate and subsequent stock price reaction to an accident announcement. ${ }^{8}$

\section{DATA}

The sample contains data on railroad accidents as published by the U.S. National Transportation Safety Board (NTSB). On its website (www. 
ntsb.gov) the NTSB provides information on railroad accidents involving U.S. and Canadian owned trains dating back to 1967. Specifically, the database covers information on accidents involving interstate passenger and cargo trains as well as local transit systems and commuter trains. $^{9,10}$ While detailed information on accidents in early years is scarce, the NTSB provides detailed information for accidents it investigated after 1993. Among other things, accident reports published by the NTSB provide a description of the accident, an analysis of the accident cause, and a summary of accident outcomes, including the number of injuries and fatalities and an estimate of total property damages.

Because some of the records maintained by the NTSB are incomplete, additional online databases including the website of the Federal Railroad Administration's Office of Safety Analysis (http://safetydata.fra.dot.gov) and the U.S. Department of Transportation, Bureau of Transportation Statistics (http://www.transtats. bts.gov) were accessed to complete the data set. To ensure consistency in sample formation, overlapping records were cross referenced and compared between the databases. No significant inconsistencies were found. ${ }^{11}$

To ensure that only information that was readily available to investors after an accident is included in the analysis, Lexis/Nexis was accessed to retrieve information on the accident causes and consequences that were reported in initial news reports and prior to an official investigation by the NTSB and other agencies. In cases where initial news reports differed from later NTSB findings, data from the news reports was used in the analysis.

To ensure that the sample only includes accidents that present a meaningful financial risk to the involved company and its stakeholders, "minor" accidents were excluded from the sample. To be included in the sample, an accident must have resulted in at least one of the following: a fatality, at least 50 injuries, estimated property damages of at least $\$ 10$ million, or a hazardous material spill. ${ }^{12}$ Accidents that did not fulfill at least one of these criteria were dropped from the sample. Furthermore, accidents caused by third parties, such as motor vehicle drivers who caused a collision due to inattentive or unlawful behavior at a railroad crossing, were deleted from the sample. In cases where two or more trains from different railroad companies were involved in an accident, only the impact on the railroad company that was found to be responsible for the accident was analyzed.

Daily stock price returns, adjusted for dividends and stock splits, and information on the daily market capitalization for all publicly traded railroad companies were retrieved from the Center for Research in Security Prices at the University of Chicago Graduate School of Business (CRSP). For U.S. firms, the Standard and Poor S\&P 500 market index (also retrieved through CRSP) was used to proxy for market returns. In addition, weekly three-month U.S. Treasury Security indexes as reported by the U.S. Treasury Department and the Federal Reserve were employed as a proxy for the riskfree interest rate during the sample period. For Canadian firms, the TSE 300 was used as a market proxy, and weekly data on annualized three-month Treasury Bill yields, as calculated by the Bank of Canada, was employed as a proxy for the risk-free interest rate..$^{13}$

Table 1 provides summary statistics for the sample. As shown in Table 1, the dataset includes information on 26 railroad accidents involving trains owned by publicly traded U.S. and Canadian companies between January 1, 1993 and December 31, 2003. More than 300 people were injured and 23 people lost their lives in these accidents. Ten accidents resulted in hazardous material spills (not counting fuel spills from damaged locomotives) and estimated railroad property damages exceeded U.S. \$109 million.

\section{Definition of Variables}

For each railroad accident a variety of variables were recorded, including the name of the involved railroad company/companies, the date and location of the accident, the number of injuries and fatalities, and estimated property damages. In addition, a dummy variable was defined that indicates whether or not the crash resulted in a hazardous material spill.

To account for possible differences between the U.S. and Canadian stock markets, a dummy 
Table 1: Summary Statistics

\begin{tabular}{|c|c|c|c|c|c|}
\hline & $\begin{array}{c}\text { Number of } \\
\text { Railroad } \\
\text { Accidents }\end{array}$ & $\begin{array}{c}\text { Total Property } \\
\text { Damage } \\
\text { (US\$, Million) }\end{array}$ & $\begin{array}{l}\text { Number of } \\
\text { Injuries }\end{array}$ & $\begin{array}{l}\text { Number of } \\
\text { Fatalities }\end{array}$ & $\begin{array}{c}\text { Accidents with } \\
\text { Hazardous } \\
\text { Material Spills }\end{array}$ \\
\hline \multicolumn{6}{|c|}{ Panel A. All Railroad Accidents } \\
\hline $\begin{array}{c}\text { Entire sample period } \\
1993-2003\end{array}$ & 26 & 109.01 & 318 & 23 & 10 \\
\hline \multicolumn{6}{|c|}{ Panel B. Summary Statistics by Year } \\
\hline 1993 & 1 & 14.00 & 59 & 0 & 0 \\
\hline 1994 & - & - & - & - & - \\
\hline 1995 & - & - & - & - & - \\
\hline 1996 & 4 & 12.05 & 3 & 3 & 2 \\
\hline 1997 & 6 & 7.23 & 4 & 6 & 3 \\
\hline 1998 & 1 & 2.60 & 0 & 0 & 1 \\
\hline 1999 & 3 & 6.53 & 4 & 4 & 0 \\
\hline 2000 & 3 & 35.00 & 12 & 4 & 1 \\
\hline 2001 & 3 & 13.68 & 69 & 2 & 1 \\
\hline 2002 & 3 & 13.62 & 165 & 3 & 1 \\
\hline 2003 & 2 & 4.30 & 2 & 1 & 1 \\
\hline
\end{tabular}

The table provides summary statistics for the sample of 26 railroad accidents between January 1, 1993, and December 31, 2003, involving railroad companies traded on a U.S. or Canadian exchange. Panel A contains aggregate statistics for the entire sample period. Panel B provides a breakdown by year.

variable was created that distinguishes between accidents involving trains operated by U.S. and Canadian companies.

Finally, to control for the size of the involved firms, the natural log of the market capitalization of each railroad company one day before the accident was calculated. Similarly, the natural $\log$ of the estimated property damages was calculated to measure direct economic costs associated with the accident. Expressing the variable in logs helps resolve problems related to non-normality encountered for both variables during preliminary tests and allows for a percentage-based interpretation of their regression coefficients. ${ }^{14}$ For consistency, each firm's market capitalization and estimated property damages were discounted back to 1993 using CPI inflation rates published by the U.S. Bureau of Labor Statistics (BLS) or the Bank of Canada. An exact variable definition is provided in Table 2.

\section{Classification of Accident Causes}

We hypothesize that the cause of an accident influences the way the market reacts to the corresponding news announcement. Reckless behavior on behalf of the crew or controller, including speeding, intoxication or drug abuse, for example, is likely to be followed by more media coverage and larger legal claims against the railroad company than a non-reckless crew error or the discovery of a mechanical malfunction of train equipment, a damaged track, or a signal failure.

On the other hand, it is expected that the presence of poor weather conditions at the crash site reduces the legal liability of the railroad firm. Fog, for example, that made it difficult for a train operator to spot a signal or the presence of ice on the tracks that made it even tougher than usual for the train operator to bring the train to a timely halt may be viewed 
Table 2: Variable Definitions

\begin{tabular}{|c|c|c|}
\hline Variable & Data Source & Description \\
\hline ln(MKTCAP) & $\begin{array}{c}\text { CRSP, BLS / } \\
\text { Bank of Canada }\end{array}$ & $\begin{array}{l}\text { Natural log of the railroad company's market } \\
\text { capitalization one day prior to the accident date, } \\
\text { converted to } 1993 \text { dollars based on CPI data from } \\
\text { the Bureau of Labor Statistics (BLS) or the Bank of } \\
\text { Canada }\end{array}$ \\
\hline $\ln (\mathrm{DAMAGE})$ & $\begin{array}{c}\text { NTSB, BLS / } \\
\text { Bank of Canada }\end{array}$ & $\begin{array}{l}\text { Natural log of estimated property damages, converted } \\
\text { to } 1993 \text { dollars based on CPI data from the Bureau of } \\
\text { Labor Statistics (BLS) or the Bank of Canada }\end{array}$ \\
\hline US RAILROAD & NTSB & $\begin{array}{l}\text { Dummy variable that indicates whether or not the } \\
\text { affected railroad company is headquartered in the } \\
\text { U.S. }(1=\text { yes, } 0=\text { no })^{15}\end{array}$ \\
\hline FATALITIES & NTSB & $\begin{array}{l}\text { Number of fatalities (crew, passengers, and third } \\
\text { parties) }\end{array}$ \\
\hline INJURIES & NTSB & $\begin{array}{l}\text { Number of people injured (crew, passengers, and } \\
\text { third parties) }\end{array}$ \\
\hline HAZMAT SPILL & NTSB & $\begin{array}{l}\text { Dummy variable that indicates whether or not the } \\
\text { accident resulted in a hazardous material spill ( } 1=\text { yes, } \\
0=\text { no) }\end{array}$ \\
\hline
\end{tabular}

as a mitigating factor when determining the company's legal liability.

To ensure that the analysis is only based on publicly available information (i.e., information that investors could actually react to), various news services including Lexis/ Nexis, Bloomberg, and Reuters were accessed to determine what accident causes were reported in the initial news reports. If the cause was unknown within 24 hours of the accident and was only later determined by the NTSB, the accident was classified as "cause unknown." Table 3 provides an overview of the accident classification.

\section{RESULTS}

The empirical analysis starts by examining the stock price reaction of railroad companies to railroad accidents over various time horizons after the event. Table 4 provides an overview of the short-term results. The event day is denoted as day 0 . Because it was impossible to identify for every accident whether it was announced prior to or after the market close, a railroad stock's immediate price reaction was measured as the cumulative abnormal return during days 0 and 1 . This ensures that if the event took place or was announced after 4:00 p.m. Eastern Time (the close of the major U.S. and Canadian stock markets), the market's reaction is captured on the day after the event.

Although stock price declines during an $(0,1)$ event window (i.e., on the day of the accident and the following trading day) are well above $4 \%$ in some instances, our aggregate results across the whole sample are only weakly significant. While we observe an average stock price decline of $1.48 \%$ on those two days, the $\mathrm{p}$-values from a t-test and Wilcoxon signed rank test are only slightly lower than 0.05 , suggesting that they are only marginally significant at the $5 \%$ significance level. Moreover, a reversal of the initial stock price decline is observed within a few days after the announcement and generally insignificant results over event periods of more than three days, suggesting that investor behavior following railroad accidents is similar 
Table 3: Classification of Accident Causes

\begin{tabular}{|c|c|c|}
\hline Variable & Data Source & Description \\
\hline MECHANICAL & $\begin{array}{l}\text { NTSB, Lexis/Nexis, } \\
\text { Bloomberg, Reuters }\end{array}$ & $\begin{array}{l}\text { Mechanical failure, e.g. equipment or } \\
\text { instrument failure, damaged tracks, signal } \\
\text { failure (dummy variable: } 1=\text { yes, } 0=\text { no) }\end{array}$ \\
\hline HUMAN ERROR & $\begin{array}{l}\text { NTSB, Lexis/Nexis, } \\
\text { Bloomberg, Reuters }\end{array}$ & $\begin{array}{l}\text { Error by train operator or controller/dispatcher, } \\
\text { e.g. fatigue, miscommunication (dummy } \\
\text { variable: } 1=\text { yes, } 0=\text { no) }\end{array}$ \\
\hline RECKLESSNESS & $\begin{array}{l}\text { NTSB, Lexis/Nexis, } \\
\text { Bloomberg, Reuters }\end{array}$ & $\begin{array}{l}\text { Reckless or illegal behavior by train operator or } \\
\text { controller/dispatcher, e.g. alcohol and/or other } \\
\text { drug abuse, speeding, absence from primary } \\
\text { job site (dummy variable: } 1=\text { yes, } 0=\text { no) }\end{array}$ \\
\hline OTHER & $\begin{array}{l}\text { NTSB, Lexis/Nexis, } \\
\text { Bloomberg, Reuters }\end{array}$ & $\begin{array}{l}\text { Other/unknown cause (dummy variable: } 1=\text { yes, } \\
0=\text { no) }\end{array}$ \\
\hline POOR WEATHER & $\begin{array}{l}\text { NTSB, Lexis/Nexis, } \\
\text { Bloomberg, Reuters }\end{array}$ & $\begin{array}{l}\text { Poor weather conditions, e.g. fog and/or ice on } \\
\text { crash site (dummy variable: } 1=\text { yes, } 0=\text { no) }\end{array}$ \\
\hline
\end{tabular}

Table 4: Abnormal Performance of Railroad Firms Following Train Accidents

\begin{tabular}{cccc}
\hline $\begin{array}{c}\text { Number of Trading Days } \\
\text { After Announcement }\end{array}$ & $\begin{array}{c}\text { Cumulative } \\
\text { Abnormal Returns }\end{array}$ & $\begin{array}{c}\text { t-Test } \\
\text { (p-value) }\end{array}$ & $\begin{array}{c}\text { Signed Rank } \\
\text { Test (p-value) }\end{array}$ \\
\hline 0 to 1 days & $-1.48 \%$ & 0.042 & 0.039 \\
0 to 2 days & $-1.90 \%$ & 0.048 & 0.040 \\
0 to 5 days (1 week) & $-1.31 \%$ & 0.106 & 0.083 \\
0 to 7 days (1.5 weeks) & $-0.94 \%$ & 0.195 & 0.177 \\
0 to 10 days (2 weeks) & $-0.27 \%$ & 0.434 & 0.472 \\
0 to 21 days (1 month) & $-0.19 \%$ & 0.785 & 0.601 \\
0 to 63 days (3 months) & $0.42 \%$ & 0.714 & 0.625 \\
0 to 125 days (6 months) & $0.57 \%$ & 0.883 & 0.807 \\
0 to 250 days (1 year) & $0.28 \%$ & 0.961 & 0.959 \\
\hline
\end{tabular}

in spirit to the investor behavior following aviation accidents observed by Davidson et al. (1987). To ensure that the results are robust to variations in sample selection criteria, the requirements were varied (i.e., the minimum number of injuries, fatalities, property damages, and hazardous material spills that were set during the initial sample construction). Not surprisingly, the event study results became economically and statistically more significant when selecting only larger accidents (i.e., accidents with a higher number of fatalities, injuries, or property damages). Due to the accompanying decline in sample size, however, we decided to report the results for the initial sample of 26 accidents. The larger size of this sample has an advantage in that it allows for an examination of the variation in cumulative abnormal returns through a series of univariate tests and regression analysis, which becomes difficult when the sample size is too small.

Figure 1 presents the results graphically by plotting the cumulative abnormal returns of railroad companies within 20 trading days prior to and after the accident. Since the event is unanticipated, there should be no price 
Figure 1: Cumulative Abnormal Returns Around Railroad Accidents

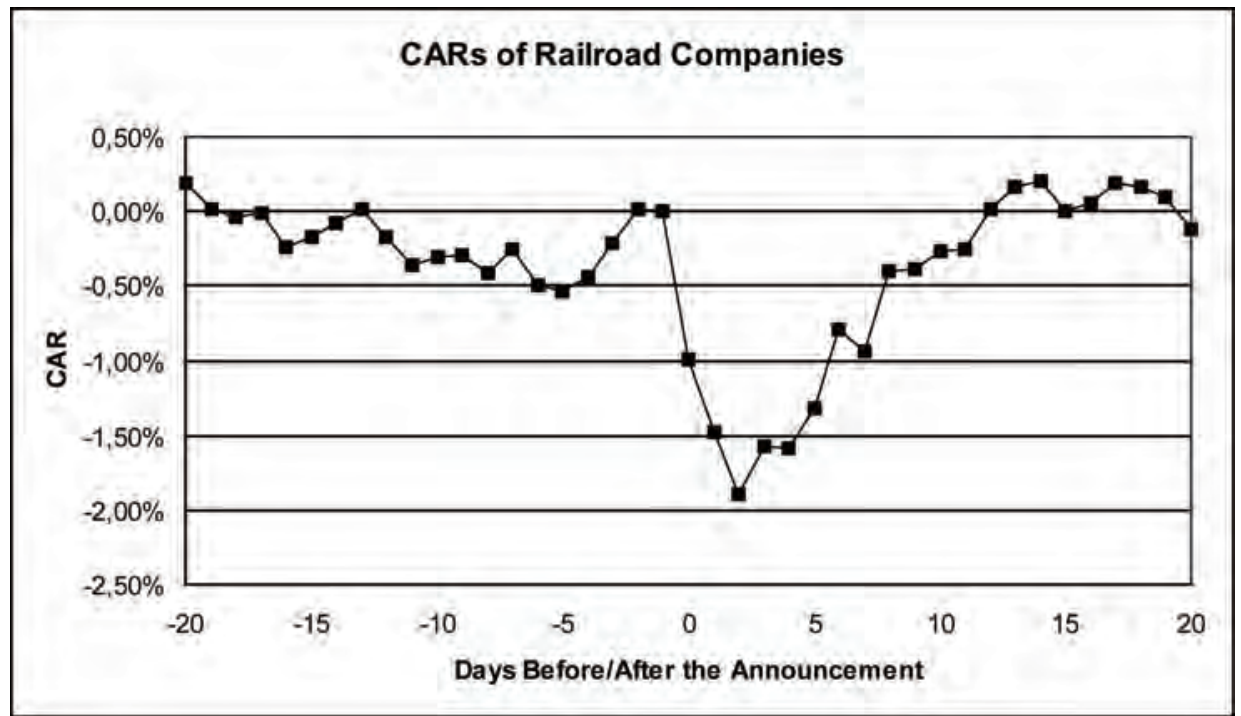

Cumulative abnormal returns were calculated for railroad companies during the 20 training days prior to and after a railroad accident (day 0).

movements before the event. The pre-event period is useful, however, for comparing with the post-event period. In Figure 1 the stock price drops on days 0 and 1 , followed by an almost complete recovery during the next seven days of trading. This is somewhat surprising as it is inconsistent with the efficient market hypothesis, which states that stock prices should immediately and correctly adjust to an announcement, and that subsequent price corrections should not be observed. The significance of this observation was tested and it was found that the price recovery of $1.63 \%$ observed between day 2 and day 10 is significant by itself even when ignoring the price decline of $1.90 \%$ during the preceding $(0,2)$ event window.

Not surprisingly, there are no clear trends in Figure 1 prior to the accident. In contrast to other studies which often examine the effects of information leakage prior to an announcement, such an analysis is not necessary in this case.

\section{Univariate Analysis}

To provide some intuition for the variables used in the subsequent regression analysis, a series of univariate tests was performed. These tests are useful to examine whether mean and median cumulative abnormal returns for railroad companies vary across various subsamples of the dataset. Two-sample t-tests were used to test for the significance of differences in means; and Kruskal-Wallis median tests were employed to test for the significance of differences in medians between each set of subsamples. Median tests have the advantage of being more robust to outliers and extreme observations. Subsamples were constructed based on various factors that characterize the respective firm or the accident. The results are presented in Table 5.

Firm characteristics, such as market capitalization and national origin, explain little of the differences in CARs. Factors that pertain directly to the accident, however, provide interesting insights into the reasons why investors react differently to various types of accidents. In particular, accidents that result in hazardous material spills cause significantly larger price declines during the first two days of trading $(-3.26 \%)$ than accidents that did not cause hazardous material spills $(-0.95 \%)$. This is consistent with initial expectations and suggests that investors incorporate expected direct and indirect costs (which tend to be significantly higher for such accidents due 
Table 5: Preliminary Examination of Cumulative Abnormal Returns

\begin{tabular}{|c|c|c|c|c|}
\hline Subsample 1 & $\begin{array}{l}\mathrm{N}, \\
\text { mean, } \\
\text { median }\end{array}$ & Subsample 2 & $\begin{array}{l}\mathrm{N}, \\
\text { mean, } \\
\text { median }\end{array}$ & $\begin{array}{c}\text { Tests of differences } \\
\text { means (p-value) } \\
\text { medians (p-value) }\end{array}$ \\
\hline $\begin{array}{l}\text { Large Railroad Firms } \\
\text { (Market Capitalization } \\
\text { > US\$10 Billion) }\end{array}$ & $\begin{array}{c}9 \\
-1.50 \% \\
-1.86 \%\end{array}$ & $\begin{array}{l}\text { Small Railroad Firms } \\
\text { (Market Capitalization } \\
\text { < US\$10 Billion) }\end{array}$ & $\begin{array}{c}17 \\
-1.48 \% \\
-1.12 \%\end{array}$ & $\begin{array}{l}0.931 \\
0.337\end{array}$ \\
\hline U.S. Railroad Firms & $\begin{array}{c}22 \\
-1.64 \% \\
-1.37 \%\end{array}$ & Canadian Railroad Firms & $\begin{array}{c}4 \\
-0.63 \% \\
0.08 \%\end{array}$ & $\begin{array}{l}0.116 \\
0.085\end{array}$ \\
\hline $\begin{array}{l}\text { Accidents with Property } \\
\text { Damage > US\$5 Million }\end{array}$ & $\begin{array}{c}10 \\
-2.73 \% \\
-1.42 \%\end{array}$ & $\begin{array}{l}\text { Accidents with Property } \\
\text { Damage }<\text { US\$5 Million }\end{array}$ & $\begin{array}{c}16 \\
-0.70 \% \\
-0.96 \%\end{array}$ & $\begin{array}{l}0.074 \\
0.091\end{array}$ \\
\hline $\begin{array}{l}\text { Accidents with more } \\
\text { than } 2 \text { Fatalities }\end{array}$ & $\begin{array}{c}11 \\
-1.73 \% \\
-1.23 \%\end{array}$ & $\begin{array}{c}\text { Accidents with less than } 2 \\
\text { Fatalities }\end{array}$ & $\begin{array}{c}15 \\
-1.30 \% \\
-0.83 \%\end{array}$ & $\begin{array}{l}0.352 \\
0.264\end{array}$ \\
\hline $\begin{array}{l}\text { Accidents with more } \\
\text { than } 50 \text { Injuries }\end{array}$ & $\begin{array}{c}6 \\
-2.77 \% \\
-2.02 \%\end{array}$ & $\begin{array}{l}\text { Accidents with less than } \\
50 \text { Injuries }\end{array}$ & $\begin{array}{c}20 \\
-1.10 \% \\
-0.79 \%\end{array}$ & $\begin{array}{l}0.049 \\
0.027\end{array}$ \\
\hline $\begin{array}{c}\text { Accidents with } \\
\text { Hazardous Material } \\
\text { Spills }\end{array}$ & $\begin{array}{c}6 \\
-3.26 \% \\
-3.67 \%\end{array}$ & $\begin{array}{c}\text { Accidents without } \\
\text { Hazardous Material Spills }\end{array}$ & $\begin{array}{c}20 \\
-0.95 \% \\
-0.68 \%\end{array}$ & $\begin{array}{l}0.031 \\
0.014\end{array}$ \\
\hline $\begin{array}{l}\text { Accident Caused by } \\
\text { Mechanical Errors or } \\
\text { Equipment Malfunction }\end{array}$ & $\begin{array}{c}8 \\
-1.08 \% \\
-0.89 \%\end{array}$ & All Other Causes & $\begin{array}{c}18 \\
-1.66 \% \\
-1.38 \%\end{array}$ & $\begin{array}{l}0.128 \\
0.177\end{array}$ \\
\hline $\begin{array}{l}\text { Accident Caused by } \\
\text { Human Error (by Train } \\
\text { Crew or Controllers) }\end{array}$ & $\begin{array}{c}10 \\
-1.27 \% \\
-1.14 \%\end{array}$ & All Other Causes & $\begin{array}{c}16 \\
-1.62 \% \\
-1.21 \%\end{array}$ & $\begin{array}{l}0.437 \\
0.877\end{array}$ \\
\hline $\begin{array}{l}\text { Accident Caused by } \\
\text { Reckless Behavior }\end{array}$ & $\begin{array}{c}5 \\
-2.09 \% \\
-1.43 \%\end{array}$ & All Other Causes & $\begin{array}{c}21 \\
-1.34 \% \\
-0.83 \%\end{array}$ & $\begin{array}{l}0.092 \\
0.068\end{array}$ \\
\hline $\begin{array}{c}\text { Poor Weather Conditions } \\
\text { on Accident Site (Fog } \\
\text { and/or Ice) }\end{array}$ & $\begin{array}{c}4 \\
-0.33 \% \\
-0.83 \%\end{array}$ & $\begin{array}{l}\text { No Unusual Weather } \\
\text { Conditions }\end{array}$ & $\begin{array}{c}22 \\
-1.69 \% \\
-1.23 \%\end{array}$ & $\begin{array}{l}0.174 \\
0.392\end{array}$ \\
\hline
\end{tabular}

Subsets of the sample were formed by distinguishing between small and large railroad companies (based on the firms' discounted market capitalization), U.S. and Canadian firms, accidents that caused more or less than US\$5 million in property damage, accidents that involved (or did not involve) hazardous material spills, accidents that involved less than or more than two fatalities, and crashes that involved less than or more than 50 injuries. In addition, the subsets distinguish between accidents caused by mechanical failures, human errors, and reckless behavior (versus other causes). Finally, the subsamples distinguish between accidents that occurred during poor weather conditions (fog and/or ice on the accident site) and accidents that occurred under regular weather conditions. For each subsample, the number of observations N, as well as mean and median cumulative abnormal returns (CARs) during a $(0,1)$ event window are reported. T-tests and Kruskal-Wallis tests are employed to test for the equality of mean and median CARs between each set of subsamples. The last column reports p-values for both tests. 
to higher than expected cleanup costs, bad publicity, and potentially large legal liability claims) into their trading decisions.

Similarly, accidents that led to more than 50 injuries caused a significantly larger stock price decline $(-2.77 \%)$ than accidents in which less than 50 people were injured $(-1.10 \%){ }^{16}$ A similar, although less significant, difference can be observed when comparing accidents that resulted in fewer than or more than two fatalities. ${ }^{17}$ Finally, it was investigated whether different accident causes lead to different investor reactions. As expected, accidents caused by mechanical failures or non-reckless human errors entail smaller stock price declines than accidents that resulted from reckless behavior by one of the railroad company's employees. Punitive damage awards for the plaintiffs tend to be particularly high in such cases as plaintiff lawyers are often successful in arguing that the company was grossly negligent in allowing such misconduct. In addition, the bad publicity arising from such an incident and possible consumer mistrust in the safety standards of the involved railroad company are hypothesized to cause a stronger market reaction.

As expected, accidents that occurred during poor weather conditions are associated with a somewhat smaller price drop $(-0.33 \%)$ than accidents that occurred under no unusual weather conditions $(-1.69 \%)$, but the difference is statistically insignificant.

\section{Correlation Analysis}

Table 6 displays the correlation matrix of independent variables that are hypothesized to have an impact on abnormal returns. Judging by the magnitude and significance of the correlation coefficients, there is little reason to be concerned about multicollinearity in the model.

Only two variables have a correlation coefficient that is larger than 0.7 in absolute terms: the natural $\log$ of a firm's market capitalization and its national origin (U.S. versus Canadian firms). This is not surprising as the market capitalization of the Canadian firms in the sample tends to be much lower than that of U.S. firms. To ensure that the regression results are not affected by a potential multicollinearity problem that might arise when including both variables, models in which either of these variables was excluded were also estimated. Since the magnitude and significance of the regression coefficients was little affected, we decided to report regression results for the full model specification in the following section.

\section{Regression Analysis}

Because univariate analysis only allows for an examination of the impact of one factor at a time without controlling for changes in other variables, ordinary least squares (OLS) regressions for railroad company CARs during various event windows after each accident were performed.

Table 7 contains results for five regressions in which CARs were regressed against a variety of variables that characterize both the company itself and the accident it experienced. The discussion focuses on the second column in which regression results for the abnormal return the railroad experienced during its first two days of trading (i.e., during the $(0,1)$ event window) are presented. The results are largely consistent with the results from the univariate analysis. Accidents resulting in many injuries or fatalities, as well as accidents involving hazardous material spills, cause significantly larger price declines. While a breakdown by national origin and size provided no significant results in the univariate analysis, both variables become significant in the regression model. Specifically, larger firms are more affected by accidents than smaller firms. Similarly, U.S. firms are more affected than Canadian firms. While one might think that larger firms should be in a better position to absorb the losses from an accident, the results are consistent with Alexander (1991), who argues that plaintiffs preferentially seek out “deep pocket” defendants in hopes of extracting larger settlements, and with an aviation study by Thiengtham and Walker (2005), who observe a stronger stock price reaction for large airlines following aviation disasters. The fact that Canadian railroad firms, after controlling for size, show a smaller price decline after an accident is 
Table 6: Correlation Matrix of Independent Variables

\begin{tabular}{|c|c|c|c|c|c|c|c|c|c|}
\hline & Ln(mktcap) & Ln(damage) & US Railroad & Fatalities & Injuries & $\begin{array}{c}\text { Hazmat } \\
\text { Spill }\end{array}$ & Mechanical & $\begin{array}{c}\text { Human } \\
\text { Error }\end{array}$ & Recklessness \\
\hline Ln(damage) & 0.098 & & & & & & & & \\
\hline Us railroad & 0.752 & -0.009 & & & & & & & \\
\hline Fatalities & -0.187 & -0.408 & -0.212 & & & & & & \\
\hline Injuries & 0.052 & 0.092 & 0.146 & 0.039 & & & & & \\
\hline Hazmat spill & 0.262 & 0.326 & 0.158 & -0.403 & -0.282 & & & & \\
\hline Mechanical & 0.273 & 0.202 & 0.192 & -0.245 & 0.466 & 0.426 & & & \\
\hline Human error & 0.297 & 0.209 & 0.158 & 0.403 & 0.367 & 0.133 & 0.426 & & \\
\hline Recklessness & -0.358 & -0.361 & -0.192 & 0.010 & 0.342 & -0.572 & -0.278 & -0.426 & \\
\hline Poor weather & 0.002 & 0.078 & 0.083 & 0.212 & -0.146 & -0.158 & -0.192 & -0.158 & 0.192 \\
\hline
\end{tabular}

For each pair of variables, the Pearson correlation coefficient was calculated using the following formula:

$$
r=\frac{\sum(x-\bar{x})(y-\bar{y})}{(n-1) s_{1} s_{2}}
$$

where $\bar{x}$ and $\mathrm{s}_{1}$ are the sample mean and standard deviation for the first sample, $\bar{y}$ and $\mathrm{s}_{2}$ are the same for the second sample, and $\mathrm{n}$ is the sample size.

somewhat surprising, especially since they can be sued under U.S. law if they were involved in an accident on U.S. territory.

As in the univariate analysis, mechanical failures are generally associated with a smaller price decline. On the other hand, accidents caused by reckless behavior entail significantly larger stock price drops. Interestingly, the presence of poor weather conditions tends to mitigate price declines, likely as a result of a lower probability to be found responsible for the accident.

The regression model fits very well when examining short-term CARs and explains approximately $84 \%$ of the variation in returns during the $(0,1)$ event window (i.e., during the first two days of trading). When examining longer-term returns, the model provides a poorer fit, and both the size and statistical significance of the regressors drops. From an economic perspective, the results may be interpreted as follows: a firm that is twice as large as another firm experiencing a comparable accident will experience an additional stock price decline of $0.17 \%$ during the $(0,1)$ event window. ${ }^{18}$ In the same vein, an accident that has twice the estimated damages than another accident - all else being the same - should lead to an additional stock price drop of $0.22 \%$. Similarly, the results suggest that every additional fatality or injury causes an additional stock price drop of $0.21 \%$ or $0.03 \%$, respectively. ${ }^{19}$
An interpretation of the dummy variables is also straightforward and suggests that U.S. railroads suffer a price decline that is approximately $0.42 \%$ larger than that of Canadian railroads involved in similar accidents. Similarly, hazardous material spills lead to a highly significant additional stock price decline of $0.76 \%$ during the first two days of trading. Finally, while human errors as potential accident causes appear to explain little of the variation in abnormal returns, crashes caused by mechanical failures lead to price declines that are $0.24 \%$ smaller than other accidents. In contrast, accidents caused by reckless behavior tend to cause a stock price drop that is $0.33 \%$ larger than that of other accidents. This relationship is expected as reckless behavior leads to potentially larger damage awards when a case is decided through a jury verdict. The presence of poor weather conditions reduces price declines by a marginally significant $0.22 \%$.

\section{CONCLUSIONS}

That train accidents have a negative impact on the stock performance of the involved railroad companies comes as no surprise. However, why certain types of accidents cause large price declines while others have almost no impact is puzzling.. This question was addressed by exploring the factors behind a railroad 
Table 7: OLS Regression Analysis of Abnormal Returns

\begin{tabular}{|c|c|c|c|c|c|}
\hline & $(0,1) \mathrm{CAR}$ & $(0,2) \mathrm{CAR}$ & $(0,5) \mathrm{CAR}$ & $(0,10) \mathrm{CAR}$ & $(0,21)$ CAR \\
\hline Variable & $\begin{array}{c}\text { Coefficient } \\
\text { (p-value) }\end{array}$ & $\begin{array}{c}\text { Coefficient } \\
\text { (p-value) }\end{array}$ & $\begin{array}{c}\text { Coefficient } \\
\text { (p-value) }\end{array}$ & $\begin{array}{c}\text { Coefficient } \\
\text { (p-value) }\end{array}$ & $\begin{array}{c}\text { Coefficient } \\
\text { (p-value) }\end{array}$ \\
\hline Intercept & 0.5823 & 0.7792 & 1.1102 & 1.2440 & 1.6770 \\
\hline $\ln (\mathrm{MKTCAP})$ & $\begin{array}{c}(0.041) \\
-0.2483 \\
(0.033)\end{array}$ & $\begin{array}{c}(0.071) \\
-0.2396 \\
(0.052)\end{array}$ & $\begin{array}{c}(0.114) \\
-0.2012 \\
(0.103)\end{array}$ & $\begin{array}{c}(0.095) \\
-0.1895 \\
(0.095)\end{array}$ & $\begin{array}{l}(0.196) \\
-0.1712 \\
(0.184)\end{array}$ \\
\hline $\ln (\mathrm{DAMAGE})$ & $\begin{array}{c}-0.3143 \\
(0.029)\end{array}$ & $\begin{array}{r}-0.3121 \\
(0.090)\end{array}$ & $\begin{array}{l}-0.3155 \\
(0.197)\end{array}$ & $\begin{array}{c}-0.4108 \\
(0.176)\end{array}$ & $\begin{array}{l}-0.3197 \\
(0.431)\end{array}$ \\
\hline US Railroad & $\begin{array}{r}-0.4217 \\
(0.041)\end{array}$ & $\begin{array}{c}-0.2360 \\
(0.059)\end{array}$ & $\begin{array}{l}-0.1198 \\
(0.231)\end{array}$ & $\begin{array}{c}-0.0311 \\
(0.577)\end{array}$ & $\begin{array}{l}0.0275 \\
(0.815)\end{array}$ \\
\hline Fatalities & $\begin{array}{c}-0.2128 \\
(0.061)\end{array}$ & $\begin{array}{c}-0.2134 \\
(0.078)\end{array}$ & $\begin{array}{r}-0.1917 \\
(0.134)\end{array}$ & $\begin{array}{c}-0.1703 \\
(0.093)\end{array}$ & $\begin{array}{c}-0.1871 \\
(0.180)\end{array}$ \\
\hline Injuries & $\begin{array}{l}-0.0310 \\
(0.041)\end{array}$ & $\begin{array}{c}-0.0523 \\
(0.064)\end{array}$ & $\begin{array}{c}-0.0233 \\
(0.364)\end{array}$ & $\begin{array}{l}0.0106 \\
(0.297)\end{array}$ & $\begin{array}{l}0.0092 \\
(0.926)\end{array}$ \\
\hline HAZMAT Spill & $\begin{array}{c}-0.7580 \\
(0.006)\end{array}$ & $\begin{array}{c}-0.7183 \\
(0.017)\end{array}$ & $\begin{array}{c}-0.5226 \\
(0.090)\end{array}$ & $\begin{array}{c}-0.4363 \\
(0.121)\end{array}$ & $\begin{array}{c}-0.3158 \\
(0.196)\end{array}$ \\
\hline Mechanical & $\begin{array}{l}0.2402 \\
(0.081)\end{array}$ & $\begin{array}{l}0.1566 \\
(0.105)\end{array}$ & $\begin{array}{l}0.1598 \\
(0.347)\end{array}$ & $\begin{array}{l}0.0618 \\
(0.787)\end{array}$ & $\begin{array}{l}0.1161 \\
(0.859)\end{array}$ \\
\hline Human Error & $\begin{array}{l}0.1235 \\
(0.425)\end{array}$ & $\begin{array}{l}0.0780 \\
(0.451)\end{array}$ & $\begin{array}{l}0.0369 \\
(0.592)\end{array}$ & $\begin{array}{l}0.0104 \\
(0.667)\end{array}$ & $\begin{array}{l}0.0118 \\
(0.836)\end{array}$ \\
\hline Recklessness & $\begin{array}{r}-0.3271 \\
(0.069)\end{array}$ & $\begin{array}{c}-0.2773 \\
(0.072)\end{array}$ & $\begin{array}{c}-0.1696 \\
(0.281)\end{array}$ & $\begin{array}{c}-0.2296 \\
(0.166)\end{array}$ & $\begin{array}{l}-0.2112 \\
(0.405)\end{array}$ \\
\hline Poor Weather & $\begin{array}{l}0.2205 \\
(0.098)\end{array}$ & $\begin{array}{l}0.1172 \\
(0.192)\end{array}$ & $\begin{array}{l}0.0546 \\
(0.257)\end{array}$ & $\begin{array}{l}0.1120 \\
(0.221)\end{array}$ & $\begin{array}{l}0.1106 \\
(0.444)\end{array}$ \\
\hline Adjusted R² & $84.1 \%$ & $65.4 \%$ & $51.8 \%$ & $18.4 \%$ & $11.8 \%$ \\
\hline
\end{tabular}

company's abnormal stock price performance following an accident. Anticipated legal liability claims appear to be a significant factor that drives the magnitude of a railroad stock's initial price decline. Accidents that result in many injuries or fatalities and accidents that involve hazardous material spills cause particularly large price declines. In addition, railroad stocks are particularly hard hit if the crash is caused by reckless or illegal behavior by one of its employees.

From the standpoint of investors who holds the shares of the respective railroad companies in their portfolio, a railroad accident clearly has a wealth-diminishing effect. Yet, the price decline is almost completely reversed within 10 trading days (two weeks) after the accident. For a majority of accidents, there is a short-term downward trend in a railroad's stock price that persists for approximately three trading days after the event. Subsequently, most affected railroad stocks recover to pre-event levels within a few days. Under the efficient market hypothesis, neither the prolonged downward trend during the first three days should be observed (unless the price declines are the result of delayed information dissemination) nor should there be a subsequent price recovery. 


\section{Endnotes}

1. See Savage (1998) for an extensive discussion of railroad safety.

2. See, for example, Dennis (1996) who conducts a survey of hazardous rail accidents between 1982 and 1992 and evaluates their costs for the involved railroad companies.

3. The Federal Railroad Administration (FRA) provides annual railroad accident statistics. In its 2002 report, for example, the FRA lists 2,701 accidents during the year(see Table 1-1, U.S. Department of Transportation, Federal Railroad Administration, Railroad Safety Statistics, Interim Report 2002). This study applies various sample selection criteria in an attempt to focus only on major accidents that are likely to result in significant losses for the involved railroad company and its investors. In addition, the sample is restricted to accidents for which sufficient information was available.

4. While the continued price decline during the first days after an accident may be the result of slow information dissemination the subsequent price reversal should not be observed in an efficient market.

5. Sprecher and Pertl (1983) investigate the impact of large losses on firms in a variety of industry sectors. A large loss is broadly defined as the loss of property, the loss of productive capacity, or a large liability claim that is expected to result in damages of at least $10 \%$ of the affected firm's total net worth.

6. See Lamb (1995) who investigates the abnormal returns for insurance firms following Hurricane Andrew and Shelor et al. (1992) who study the reaction to the California Earthquake of 1989.

7. One method that is also frequently applied is to estimate a firm's future performance using the Capital Asset Pricing Model (CAPM) of Sharpe (1964) and Lintner (1965). The CAPM expresses a firm's expected return as $E\left(R_{t}\right)=R_{f, t}+\beta_{t}\left[E\left(R_{m, t}\right)-R_{f, t}\right]$ where $\mathrm{E}\left(\mathrm{R}_{\mathrm{m}, \mathrm{t}}\right)$ is the expected return of the market on day $\mathrm{t}, \mathrm{R}_{\mathrm{f}, \mathrm{t}}$ represents the risk-free rate as measured by the return on 90day U.S. or Canadian Treasury Bills on day $t$, and $\beta_{t}$ is the estimated slope coefficient from a linear regression of the stock's past returns on the returns of the market. There are no significant qualitative or quantitative differences between the results obtained when using the CAPM model or the market model.

8. Note that there are approximately 250 trading days per year. Thus, 21 trading days are approximately equal to one calendar month.

9. For convenience, we refer to "railroad companies" and "railroad accidents" throughout this study. Accidents involving publicly traded regional transport systems such as Dallas Area Rapid Transit are also included in the sample.

10. Note that accidents involving Amtrak trains are not included in the analysis as Amtrak is not publicly traded. In unreported tests, it was investigated whether accidents involving Amtrak trains running on rails owned by freight railroads such as CSX resulted in stock price declines for the track operators. The tests suggested no abnormal performance for the freight railroads following the accident, even if poor track maintenance was blamed for the accident. As pointed out by in a recent report by the New York Times (see Bogdanich, W. "Death on the Tracks: Amtrak Pays Millions for Others' Fatal Errors.” New York Times, October 15, 2004), Amtrak has been paying accident-related liability claims arising from accidents involving its trains, regardless of fault, as a condition for using the freight lines' tracks. This indemnification agreement likely contributed to Amtrak's poor performance in recent years.

11. Note that the accidents investigated and reported on by the NTSB represent only a small subset of accidents that actually occurred in any given year. While the FRA reports information for a much larger number of railroad accidents (many of which would also fulfill this study's sample 
selection criteria), their database is not used as a primary data source as it lacks the depth that the NTSB reports provide.

12. Note that property damages reported by the NTSB and the FRA only deal with damage to railroad property such as the track, signaling equipment or rolling stock. They do not include damages to third parties, shippers’ property, or lawsuit settlements.

13. To ensure the robustness of the results, various robustness tests were performed in which alternative market proxies such as the Dow Jones Industrial Average or the CRSP valueweighted market index were used (for accidents involving U.S. railroad companies). For Canadian railroads, similar robustness tests were performed using the S\&P/TSE 60 and the TSE 100 index. The results are qualitatively and quantitatively highly robust to variations in the underlying index.

14. Other regressors such as the number of fatalities are approximately normally distributed, thus we do not apply a log transformation to these variables.

15. Note that the sample includes four accidents by Canadian railroad companies. Three accidents involved Canadian National and one accident involved Canadian Pacific Railway.

16. Although railroad companies are typically covered through legal liability insurance, other factors such as the loss of consumer confidence and higher legal costs may explain the larger stock price reaction for accidents involving many injuries, fatalities, and hazardous material spills (see also Savage (1998) who provides an extensive discussion of liability and insurance arrangements in the railroad industry).

17. While the breakpoints for the univariate analysis were arbitrarily chosen, the results are highly robust when selecting alternative breakpoints.

18. Note that the coefficient of the logged market capitalization variable is -0.2483 . To calculate the exact effect of an $\mathrm{x} \%$ increase in a logged regressor on a dependent variable, one can multiply the coefficient with $\ln (1+x / 100)$. Thus, to measure the effect of a $100 \%$ increase in market capitalization on a firm's CAR, the coefficient is multiplied with $\ln (2)$ or 0.6931 . The result is $(-0.2483) *(0.6931)$ or -0.1721 . Thus, a doubling in firm size leads to an additional price decline of approximately $0.17 \%$, other factors held constant (see Berenson et al. 2001).

19. Note that the number of fatalities or injuries is not logged Thus, the interpretation of the coefficients $(-0.2128$ and -0.0310$)$ is straightforward.

\section{References}

Alexander, J. "Do the Merits Matter? A Study of Settlements in Securities Class Actions." Stanford Law Review 43, (1991): 498-598.

Bank of Canada (http://www.bankofcanada.ca).

Berenson, M., D. Levine, and T. Krehbiel. Basic Business Statistics: Concepts and Applications. Prentice-Hall, New York, NY, 2001.

Bloomberg (http://www.bloomberg.com).

Bowen, R., R. Castanias, and L. Daley. "Intra-Industry Effects of the Accident at Three-Mile Island.” Journal of Financial and Quantitative Analysis 18, (1983): 87-112.

Brown, S. and J. Warner. “Using Daily Stock Returns: The Case of Event Studies.” Journal of Financial Economics 14, (1985): 3-31.

Board of Governors of the Federal Reserve System (http://www.federalreserve.gov).

Bureau of Labor Statistics (BLS), U.S. Department of Labor (http://stats.bls.gov). 
Bureau of the Public Debt, U.S. Department of the Treasury (http://www.publicdebt.treas.gov/).

Bureau of Transportation Statistics, U.S. Department of Transportation (http://www.transtats.bts. gov).

Carter, D. and B. Simkins. "The Market's Reaction to Unexpected, Catastrophic Events: The Case of Airline Stock Returns and the September 11 ${ }^{\text {th }}$ Attacks." Quarterly Review of Economics and Finance 44, (2004): 539-558.

Center for Research in Security Prices (CRSP), University of Chicago, Graduate School of Business (http://gsbwww.uchicago.edu/research/crsp).

Chance, D. and S. Ferris. “The Effect of Aviation Disasters on the Air Transport Industry: A Financial Market Perspective.” Journal of Transport Economics and Policy 21, (1987): 151-165.

Davidson, W., P. Chandy, and M. Cross. "Large Losses, Risk Management and Stock Returns in the Airline Industry.” Journal of Risk and Insurance 54, (1987): 162-172.

Dennis, S. "Estimating Risk Costs Per Unit of Exposure For Hazardous Materials Transported by Rail.” Logistics and Transportation Review 32, (1996): 351-375.

Fama, E., L. Fisher, and M. Jensen. "The Adjustment of Stock Prices to New Information.” International Economic Review 10, (1969): 1-21.

Federal Railroad Administration (FRA), U.S. Department of Transportation, Office of Safety Analysis (http://safetydata.fra.dot.gov).

Flouris, T. and T. Walker. "The Financial Performance of Low-Cost and Full-Service Airlines in Times of Crisis.” Canadian Journal of Administrative Sciences 22, (2004): 3-20.

Hill, J. and T. Schneeweis. "The Effect of Three Mile Island on Electric Utility Stock Prices: A Note.” Journal of Finance 38, (1983): 1285-1292.

Judge, G., R. Kill, W. Griffiths, H. Luetkepohl, and T. Lee. Introduction to the Theory and Practice of Econometrics. John Wiley \& Sons, New York, NY, 1988.

Lamb, R. "An Exposure-Based Analysis of Property-Liability Insurer Stock Values around Hurricane Andrew.” Journal of Risk and Insurance 62, (1995): 111-123.

Lexis/Nexis, Reed Elsevier Inc. (http://www.lexisnexis.com).

Lintner, J. "The Valuation of Risk Assets and the Selection of Risky Investments in Stock Portfolios and Capital Budgets.” Review of Economics and Statistics 47, (1965): 13-37.

McWilliams, A. and D. Siegel. "Event Studies in Management Research: Theoretical and Empirical Issues.” Academy of Management Journal 40, (1997): 626-657.

National Transportation Safety Board (NTSB), Records Management Division, (http://www ntsb. gov).

Reuters (http://www.reuters.com).

Savage, I. The Economics of Railroad Safety. Kluwer Academic Publishers, Boston, MA, 1998.

Sharpe, W. "Capital Asset Prices: A Theory of Market Equilibrium under Conditions of Risk." Journal of Finance 19, (1964): 425-442.

Shelor, R., D. Anderson, and M. Cross. "Gaining from Loss: Property-Liability Insurer Stock Values in the Aftermath of the 1989 California Earthquake.” Journal of Risk and Insurance 59, (1992): 476-487.

Sprecher, C. and M. Pertl. “Large Losses, Risk Management and Stock Prices.” Journal of Risk and Insurance 50, (1983): 107-117. 
Thiengtham, D. and T. Walker. "The Role of Aviation Laws and Legal Liability in Airline Disasters: A Financial Market Perspective.” Working paper, Concordia University, (2005).

Toronto Stock Exchange (http://www.tsx.com).

\section{Acknowledgements}

We are thankful to two anonymous referees and to colleagues at Concordia University for useful comments.

Thomas J. Walker is an assistant professor of finance at Concordia University in Montreal, Quebec. He holds a Ph.D. degree in finance and an MBA degree in finance and international business from Washington State University in Pullman, WA, as well as a B.S. degree in Wirtschaftsinformatik (Management Information Systems) from the Technical University of Darmstadt, Germany. Prior to his academic career, he worked for several years in the German consulting and industrial sector at such firms as Mercedes Benz, Utility Consultants International, Lahmeyer International, Telenet, and KPMG Peat Marwick, and currently provides consulting services for the Canadian government. His research interests are in IPO underpricing, securities regulation and litigation, institutional ownership, insider trading, and aviation finance. His work has been published or is forthcoming in the Canadian Journal of Administrative Sciences, the Journal of Air Transportation, and the Journal of Corporate Ownership and Control.

Kuntara Pukthuanthong is an assistant professor in finance in the College of Business at San Diego State University. She received a BA degree in economics from Chulalongkorn University, Thailand, an MBA in finance from Washington University, and a Ph.D. in finance from the University of California, Irvine. Her research interests are in the area of IPO valuation, entrepreneurial finance, and stock options. Her work has been published or is forthcoming in the Journal of Investment Management and the Journal of Corporate Ownership and Control.

Sergey S. Barabanov is an assistant professor of finance at the University of St. Thomas in Minneapolis/St. Paul. He holds a Ph.D. degree and an MBA degree in finance from Washington State University in Pullman, WA, and a Diploma of Higher Education in international economics and management from the Far Eastern National University in Vladivostok, Russia. Prior to his academic career, Dr. Barabanov worked for several international humanitarian aid organizations, the government of the Commonwealth of Northern Mariana Islands (Saipan, CNMI), and Deloitte Touche Tohmatsu International. His research interests lie in the areas of institutional ownership, hedge funds, market neutral strategy, information asymmetry, and securities litigation. 